УДК 379.85(075.8)

\title{
IНСТРУМЕНТИ ФОРМУВАННЯ ТА РОЗВИТКУ СВІТОВИХ ТУРИСТИЧНИХ КЛАСТЕРІВ
}

\section{TOOLS FOR THE FORMATION AND DEVELOPMENT OF GLOBAL TOURISM CLUSTERS}

\author{
Трусова Наталя Вікторівна \\ доктор економічних наук, профресор, \\ Таврійський державний агротехнологічний університет \\ імені Дмитра Моторного \\ ORCID: https://orcid.org/0000-0001-9773-4534 \\ Краснодєд Тетяна Леонідівна \\ кандидат економічних наук, доцент, \\ Таврійський державний агротехнологічний університет \\ імені Дмитра Моторного \\ ORCID: https://orcid.org/0000-0002-8930-3248
}

Trusova Natalia, Krasnoded Tatiana

Tavria State Agrotechnical University named after Dmytro Motornyi

\begin{abstract}
В дослідженні охарактеризовано методологічні засади оцінки потенціалу туристичних кластерів та об'єктів туристичної діяльності в європейському просторі. Визначено об'єктивну необхідність застосування кластерного підходу в дослідженні світової індустрії туризму. Зазначено, що кластерний підхід як засіб дослідження потрібен для створення просторового розвитку світових туристичних регіонів. Розглянуто індекс конкурентоспроможності за сукупністю показників, що згруповано в субіндекси. Водночас наведено перелік індикаторів, які дозволять виявити проблему розвитку туризму, забезпечити умови для повноцінного функціонування суб'єктів туристичної діяльності, збільшити обсяги залучення інвестицій, створити конкурентоздатний туристичний продукт, який максимально забезпечить потреби внутрішнього і міжнародного туризму. Наведено характеристику регіональних кластерів та здійснено кластерний аналіз інструментів, які створюють потенціал кластерів в європейській індустрії туризму.
\end{abstract}

Ключові слова: методологія, індекс конкурентоспроможності, індикатори, потенціал, туристичні кластери, туристична діяльність, європейський регіон.

В исследовании охарактеризованы методологические основы оценки потенциала туристических кластеров и объектов туристической деятельности в европейском пространстве. Определена объективная необходимость применения кластерного подхода в исследовании мировой индустрии туризма. Отмечено, что кластерный подход как средство исследования требуется для создания пространственного развития мировых туристических регионов. Рассмотрен индекс конкурентоспособности по совокупности показателей, сгруппированный в субиндексы. В то же время представлен перечень индикаторов, которые позволят выявить проблему развития туризма, обеспечить условия для полноценного функционирования субъектов туристической деятельности, увеличить объемы привлечения инвестиций, создать конкурентоспособный туристический продукт, который максимально обеспечит потребности внутреннего и международного туризма. Приведена характеристика региональных кластеров и осуществлен кластерный анализ инструментов, что создают потенциал кластеров в европейской индустрии туризма.

Ключевые слова: методология, индекс конкурентоспособности, индикаторы, потенциал, туристические кластеры, туристическая деятельность, европейский регион.

The article reveals the objective necessity of using the cluster approach in the study of the tourism industry of the European space. It is determined that the cluster approach is a necessary tool for creating the spatial development of the world's tourist regions, and the focus on the formation of competitive advantages of tourist clusters will lead to the production of creative innovative tourism products. The methodological principles of assessing the potential of objects of tourist activity and the study of factors that form the potential of the tourism industry in the European space are substantiated. The study examines the competitiveness index according to a set of indicators, which are 
grouped into four subindexes. The composition of competitiveness subindexes is revealed. In accordance with the methodology of assessing the level of effectiveness of the formation of the potential of tourist clusters, indicators determining its value are identified. A cluster analysis of the factors that create the regional potential of clusters in the tourism industry of the European space has been carried out. The features of the competitive environment in the tourism services market and its impact on the competitiveness of economic entities of the tourism industry are considered. The number and composition of tourism clusters in the EU member states is demonstrated. With the help of cluster analysis and audit, more competitive tourist clusters of the European space have been identified. A correlation analysis was carried out between the general competitiveness index of the EU member states in the field of travel and tourism and its subindexes. The results of this analysis confirm the existence of a direct relationship between these components. In order to characterize tourist clusters and determine the degree of development of their tourism potential, the process of combining clusters by the Ward method and the K-means method was used, which made it possible to determine various levels of competitiveness of the travel and tourism sector. The hierarchy of clusters according to the degree of development of the potential of the tourism industry is presented.

Keywords: methodology, competitiveness index, indicators, potential, tourist clusters, tourist activity, European region.

Постановка проблеми. Головними проблемами оцінки потенціалу кластерів в індустрії туризму є значна номенклатура компонентних характеристик, що зберігають свою предметну різноякісність та різну орізичну природу, а також тенденція до подальшого розширення та ускладнення. У туризмознавстві, на жаль, не виділено сукупність об'єктів оцінки потенціалу туристичних кластерів, оскільки рекреацію і туризм на даний час розглядають самостійними видами діяльності. Залишає поза увагою вагомі і масові напрями відпочинку та оздоровлення населення, такі як масова неорганізована (самодіяльна) рекреація, побутова рекреація, дачна та садово-городня діяльність. Водночас, цілісне й інтегроване уявлення потенціалу туристичних кластерів відповідає сучасним тенденціям формування регіональних міжгалузевих комплексів, що охоплюють всі різновиди і фрорми відпочинку та оздоровлення.

Аналіз останніх досліджень і публікацій. Економічним аналізом розвитку туристичної діяльності та механізмом фрормування конкурентного потенціалу туристичної індустрії займалися такі вчені, як М. Benedict, E. McMahon [1], E. Bergman, E. Feser [2], R. Butler [3], H. Ceballos-Lascurain [4], T. Чepнявська, С. Пасєка, В. Грановська, О. Пристемський, В. Демко [5; 6]. Вивченню природи виникнення потенціалу туристичних кластерів приділяли увагу Г. Горіна, В. Барабанова, Г. Богатирьова, О. Ніколайчук, О. Романуха [7], J. Cunha [8], S. Frederick, M. Simmons, M. Gallagher [9], C. Goeldner, J. Ritchie [10], C. Hall, S. Page [11], G. Hardin [12]. Водночас оцінка потенціалу туристичних кластерів та об'єктів туристичної діяльності лишається актуальним і ще недостатньо розробленим напрямом в туризмознавстві.
Метою дослідження $€$ обґрунтування методологічної парадигми фрормування потенціалу кластерів туристичної індустрії та методики його оцінювання на засадах систематики інструментів та компонент, які істотно розширюють мережу туристичної індустрії в європейському просторі.

Виклад основного матеріалу. Туристична індустрія, в сучасних умовах, набуває особливого стратегічного значення для розвитку країн-членів $€ С$ та їх регіонів, які володіють величезним потенціалом і мають всі передумови розвитку туристичної галузі, яка за умов ефективного фрункціонування може стати каталізатором стрімкої транссрормації держав до відтворення культурної спадщини та економічної стабільності [6].

При фрормуванні потенціалу туристичних кластерів в регіонах важливе значення має інструментарій соціально-економічного та організаційного характеру. У туристичній індустрії фрормується індекс конкурентоспроможності за сукупністю показників, які згруповано у 14 складових і об'єднано у чотири субіндекси: 1) сприятливість середовища (бізнес середовище; рівень безпеки; охорона здоров'я та гігієна; інфрраструктура інсрормаційно-комунікаційних технологій); 2) державна політика та створення сприятливих умов (пріоритетність сорери; міжнародна відкритість; цінова конкурентоспроможність; економічна стійкість); 3) інфрраструктура (інфрраструктура повітряного транспорту; інфрраструктура наземного та водного транспорту; туристична інфрраструктура); 4) природні та культурні ресурси (природні ресурси; культурні ресурси та ділові поїздки) [13-15].

Вважаємо за доцільне визначати конкурентоспроможність регіонального потенціалу туристичних кластерів за сукупністю індикаторів, які дозволять виявити проблему роз- 
витку туризму, забезпечити умови для повноцінного фрункціонування суб'єктів туристичної діяльності, збільшити обсяги залучення інвестицій, створити конкурентоздатний туристичний продукт, який максимально забезпечить потреби внутрішнього і міжнародного (в"їзного) туризму: 1) природно-рекреаційний потенціал, природні умови, історичні традиції; 2) організаційні аспекти фрормування туристичного потенціалу; 3) туристичноінфрормаційна інфрраструктура та промоція; 4) туристична індустрія; 5) безпека громади; 6) підприємницьке середовище; 7) туристичний продукт; 8) інфрраструктура; 9) подієві заходи.

Відповідно до методики оцінювання рівня ефрективності формування потенціалу кластерів туристичної індустрії, необхідним $€$ виокремлення індикаторів, що визначають його величину: загальна кількість потенційних туристичних ресурсів; величина потенціалу туристичних кластерів; субіндикатори формування потенціалу туристичних кластерів.

3 метою комплексного оцінювання регіонального потенціалу туристичних кластерів запропоновано інтегрований рівень його ефективного формування (табл. 1) [8; 10; 16; 17]:
Комплексне оцінювання інструментів ефрективності формування регіонального потенціалу туристично-рекреаційних кластерів базується на взаємозв'язку та взаємодії методичних прийомів, які дозволяють формалізувати даний процес та побудувати алгоритм його визначення: 1) вибір блоків дослідження; 2) якісне та кількісне оцінювання характеристик (експертний аналіз вагомості характеристик, інтегральне дослідження характеристик, інтегральна оцінка сукупності, характеристика туристичних об'єктів).

Кластерний підхід в туристичній індустрії $€$ оптимальним інструментом для забезпечення просторового розвитку європейських регіонів. Орієнтація на створення конкурентних переваг учасників кластера, сприяє розробці і впровадженню інноваційних проектів в туристську індустрію. За допомогою діагностики стану існуючих регіональних туристичних кластерів у країнах $Є С$ та оцінювання сегментів європейського туристичного ринку можна розробити заходи щодо удосконалення технологічних та продуктових інновацій, які відповідають реаліям нової методологічної парадигми щодо срормоутворюючих компонент та

Таблиця 1

\section{Методика обчислення інтегрованого рівня ефективного формування регіонального потенціалу кластерів туристичної індустрії}

\begin{tabular}{|c|c|c|}
\hline № & \multicolumn{2}{|c|}{ Показник, орормула, розшифрровка значень } \\
\hline \multirow[t]{2}{*}{1.} & $\begin{array}{l}\text { EP - інтегрований рівень есрективності } \\
\text { формування регіонального потенціалу } \\
\text { туристично-рекреаційних кластерів }\end{array}$ & $E P=a_{1} \times C_{m}+a_{2} \times P_{n p a}+a_{3} \times Z_{m}+a_{4} \times I_{m}$ \\
\hline & \multicolumn{2}{|c|}{$\begin{array}{l}C_{m}-\text { рівень потенціалу історико-культурних об'єктів в регіоні; } P_{\text {пра }}-\text { рівень потенціалу } \\
\text { природних заповідних зон; } Z_{m}-\text { рівень потенціалу природних умов; } I_{m}-\text { рівень потенціалу } \\
\text { туристично-рекреаційної інорраструктури регіону; } a_{1}-a_{4}-\text { коесріцієнт вагомості потенціалів. }\end{array}$} \\
\hline \multirow[t]{2}{*}{2.} & $\begin{array}{l}C_{m}-\text { рівень потенціалу історико-культурних } \\
\text { об'єктів в регіоні }\end{array}$ & $C_{m}=\frac{M_{i} \times(1+B)}{H}$ \\
\hline & \multicolumn{2}{|c|}{$\begin{array}{l}M_{i}-\text { кількість об'єктів розміщення в адміністративному центрі; } B \text { - локалізаційний } \\
\text { коеоріцієнт (визначає концентрацію туристично-рекреаційних об'єктів та їх віддаленість } \\
\text { від адміністративних центрів - історико-культурних об'єктів); } H \text { - кількість об'єктів } \\
\text { розміщених в регіоні. }\end{array}$} \\
\hline \multirow[t]{2}{*}{3.} & $\begin{array}{l}P_{\text {пра }}-\text { рівень потенціалу природних } \\
\text { заповідних зон території }\end{array}$ & $P_{n p a}=a \times Y+a \times L+a \times L_{n}+a \times L_{m}+a \times M_{n}+a \times M_{t}$ \\
\hline & \multicolumn{2}{|c|}{$\begin{array}{l}Y \text { - національний парк; } L-\text { ландшастний парк; } L_{n}-\text { ландшафтний парк національного } \\
\text { значення; } L_{m}-\text { ландшафртний парк місцевого значення; } M_{n}-\text { пам'ятники природи } \\
\text { державного значення; } M_{t}-\text { пам'ятники природи місцевого значення; } a-\text { вагомість }(1 \leq a \leq 2) \text {. }\end{array}$} \\
\hline 4. & $\begin{array}{l}Z_{m}-\text { рівень потенціалу природних умов } \\
\text { території }\end{array}$ & $Z_{m}=R+K_{y}+B_{k}+L_{e}$ \\
\hline & \multicolumn{2}{|c|}{$\begin{array}{l}R \text { - рельєф; } K_{y} \text { - кліматичні умови; } B_{k}-\text { водна компонента; } L_{e}-\text { ландшафртний естетичний } \\
\text { потенціал; } M \text { - природні оздоровчі локації; } P_{z} \text { - рівень забруднення території. }\end{array}$} \\
\hline 5. & $\begin{array}{l}I_{m}-\text { рівень потенціалу туристично- } \\
\text { рекреаційної інорраструктури }\end{array}$ & $I_{m}=$ \\
\hline
\end{tabular}


інструментів їх потенціалу для підвищення конкурентоспроможності та іміджу.

Кластерний підхід у туристичній індустрії сьогодні набуває великого значення та розповсюдження, особливо в таких державах як Іспанія, Румунія, Кіпр. На сучасному етапі в країнах-членах $€ C$ фрункціонують 68 туристично-рекреаційних кластерів. Зазначимо, що Західноєвропейський регіон $\epsilon$ «полігоном» для перевірки нових ідей в державній економічній політиці, яка заснована на кластерному підході. Робочі групи існуючих туристичних кластерів створені з таких питань: маркетинг та брендінг; розробка туристичного продукту; питання кадрової політики та підвищення якості трудових ресурсів; розвиток туристичнорекреаційної ї інфрраструктури; законодавче та регуляторне середовище. Розвиток кластерів індустрії туризму охоплює майже всі країни Європейського союзу, як економічно розвинуті, так і країни Східної та центральної Європи.

3 позиції наявності або відсутність взаємозв'язку між загальним Індексом конкурентоспроможності країн-членів ЄС у ссрері подорожей та туризму та субіндексами для фрормування есрективного регіонального потенціалу туристично-рекреаційних кластерів, проведено кореляційний аналіз.

Так, найбільш однотипний характер мають лінії загального індексу конкурентоспроможності країн у ссрері подорожей та туризму за субіндексами інфраструктури та природних і культурних ресурсів. Результати кореляційних розрахунків, здійснених нами, також підтверджують наявність прямого зв'язку між даними компонентами. Найбільший вплив на Індекс конкурентоспроможності країн у ссрері подорожей та туризму для країн ЄС має інорраструктура та її складові (коесріцієнт кореля- ції дорівнює 0.930235137) і природні та культурні ресурси (коефріцієнт кореляції дорівнює 0.891655781 ). Що стосується сприятливості середовища - його вплив на розвиток туристично-рекреаційної індустрії майже відсутній (коефріцієнт кореляції дорівнює 0.411007181). Державна політика та її компоненти в умовах розвитку європейського туристично-рекреаційного простору ніяк не впливають на конкурентоспроможність країн-членів $€ С$ у ссрері подорожей та туризму (коесріцієнт кореляції дорівнює 0.147844926).

Результатом використання ієрархічної кластеризації $€$ «дерево кластеризації» або дендрограма, тобто граср без циклів, побудований за матрицею близькості. Дендрограма дозволила зобразити взаємні зв'язки між об'єктами із заданої множини. Для аналізу обрані 12 складових Індексу конкурентоспроможності країн-членів ЄС у сорері подорожей та туризму (всього 90 складових). В якості алгоритму кластеризації було обрано метод «повних зв'язків», який врахує, що включення нового об'єкта в кластер відбувається тільки в тому випадку, якщо відстань між об'єктами не менше заданого рівня.

Для того щоб охарактеризувати кожен 3 виділених туристичних кластерів і виявити спільність країн-членів $€ C$ у межах кожного $з$ них було використано процес об'єднання кластерів методом Уорда та метод К-середніх значень, який дозволив визначити різні рівні конкурентоспроможності сфрери подорожей та туризму та потенціал розвитку. В табл. 2 наведено склад туристичних кластерів країн-членів ЄС групованих за методом Уорда та представлено їх ієрархію за ступенем розвитку потенціалу даної індустрії.

Так, середнє значення дорівнює 1.034305 , яке перевищує лише два - перший та другий регіональний потенціал туристично-рекреа-

Склад кластерів туристичної індустрії країн-членів ЄС за методом Уорда

\begin{tabular}{|c|c|l|c|}
\hline $\begin{array}{c}\text { Номер } \\
\text { кластера }\end{array}$ & $\begin{array}{c}\text { Кількість } \\
\text { об'єктів } \\
\text { в кластері }\end{array}$ & $\begin{array}{c}\text { Рівень потенціалу } \\
\text { Суристичної індустрії } \\
\text { кластерів країн-членів єс }\end{array}$ \\
\hline Кластер 1 & 3 & Великобританія, Нідерланди, Франція & 1,276647291 \\
\hline Кластер 2 & 3 & Іспанія, Італія, Німеччина & 1,246525721 \\
\hline Кластер 3 & 2 & Ірландія, Люксембург & 1,018104349 \\
\hline Кластер 4 & 6 & $\begin{array}{l}\text { Австрія, Греція, Данія, Португалія, } \\
\text { Фінляндія, Швеція }\end{array}$ & 0,987285878 \\
\hline Кластер 5 & 2 & Кіпр, Мальта & 0,94878156 \\
\hline Кластер 6 & 3 & Естонія Латвія, Литва & 0,882023793 \\
\hline Кластер 7 & 9 & $\begin{array}{l}\text { Бельгія, Болгарія, Польща, Румунія, } \\
\text { Словаччина, Словенія, Угорщина, } \\
\text { Хорватія, Чехія }\end{array}$ & 0,880769158 \\
\hline
\end{tabular}


ційних кластерів. В цілому різниця між кластерами 1-2 та 6-7 є незначною, що говорить про значний ступінь подібності характеристик розвитку туристичної індустрії між країнами, що знаходять саме в цих кластерах.

Сегментація європейського туристичного простору дозволила виокремити сім груп країн (кластерів), які мають певні подібності розвитку туристичної індустрії, та, відповідно потребують певних вимог щодо фрормування туристичної політики: кластер 1 - країни найбільшого рівня розвитку туристичної індустрії європейського простору; кластер 2 - країни дуже високого рівня розвитку туристичної індустрії європейського простору; кластери 3-7 - країни середнього рівня розвитку регіонального потенціалу туристичної індустрії європейського простору.
Висновки. Таким чином, трансформації у сорері туристичної індустрії здійснюються у глобальному масштабі європейського простору. Показники регіонального потенціалу туристичних кластерів в європейському просторі фрормують глобальну зростаючу інтернаціоналізацію, яка виявляється у поглибленні міжнародного розподілу праці, розвитку та інтенсифрікації експорту туристичних послуг, а також економічного співробітництва. Сорормована практика туристичної галузі забезпечує дієві напрями розвитку потенціалу туристичних послуг на міжрегіональному рівні. Ефективне фрункціонування туристичних кластерів, маркетингу і брендингу території дозволяє взаємодоповнити процеси створення і розвиток регіональних туристичних комплексів.

\section{СПИСОК ВИКОРИСТАНИХ ДЖЕРЕЛ:}

1. Benedict M.A., McMahon E.T. Green infrastructure: linking landscapes and communities. Washington : Island Press, 2006. 299 p.

2. Bergman E.M., Feser E.J. Industrial and Regional Clusters: Concepts and Comparative Applications. Morgantown : Regional Research Institute, 1999. 408 p.

3. Butler R. The Concept of a Tourist Area Cycle of Evolution: Implications for Management of Resources. Canadian Geographer. 2006. Vol. 24. P. 5-12.

4. Ceballos-Lascurain H. Tourism, Ecotourism and Protected Areas: The State of Nature-Based Tourism around the World and Guidelines for Its Development. Cambridge : IUCN Publications, 1996. 301 p.

5. Trusova N.V., Cherniavska T.A., Pasieka S.R., Hranovska V.Hr., Prystemskyi O.S., Demko V.S. Innovative clustering of the region in the context of increasing competitive positions of the enterprises of the tourist-recreational destination. GeoJournal of Tourism and Geosite. 2020. Vol. 33(3). P. 1126-1134.

6. Trusova N.V., Kyrylov Yu.Y., Hranovska V.Hr., Prystemskyi O.S., Sakun A.Zh. The imperatives of the development of the tourist services market in spatial polarization of the regional tourist system. GeoJournal of Tourism and Geosites. 2020. Vol. 29(2). P. 565-582.

7. 7. Gorina G.O., Barabanova V.V., Bohatyryova G.A., Nikolaichuk O.A., Romanukha O.M. Clustering of regional tourism service markets according to indicators of the functioning of subjects of tourism activity. Journal of Geology, Geography and Geoecology. 2020. Vol. 29. № 4. P. 684-692.

8. Cunha J. Tourism Cluster Competitiveness and Sustainability: Proposal for a Systemic Model to Measure the Impact of Tourism on Local Development. Brazilian Administration Review. 2005. № 2(2). P. 47-62.

9. Frederick S., Simmons M., Gallagher M. The ecological imperative for environmental design and planning. Frontiers in Ecology and the Environment. 2013. Vol. 11(7). P. 355-361.

10. Goeldner C.R., Ritchie J.R. Tourism: principles, practices, philosophies. Hoboken : John Wiley \& Sons, Inc., 2009. $626 \mathrm{p}$.

11. Hall C.M., Page S.J. The Geography of Tourism and Recreation: Environment, Place and Space. New York : Routledge, 2014. 470 p.

12. Hardin G. The Tragedy of the Commons. Science. 1968. Vol. 162(3859). P. 1243-1248.

13. Kuśen E.A. System of tourism attractions. Tourism. 2010. Vol. 58(4). P. 409-424.

14. Lindqvist G., Solvell O., Ketels Ch. The Cluster Initiative Greenbook 2.0. Stockholm : Ivory Tower Publishers, 2013. 66 p.

15. Nordin S. Tourism Clustering \& Innovation: path to economic growth and development. Östersund : European Tourism Research Institute,2003. 90 p.

16. Selin S. Developing a typology of sustainable tourism partnerships. Journal of Sustainable tourism. 1999. Vol. 7(3). P. 260-273.

17. Sevenant M., Antrop M. Cognitive attributes and aesthetic preferences in assessment and differentiation of landscapes. Journal of Environmental Management. 2009. Vol. 90. P. 2889-2899.

18. The UNWTO Tourism Dashboard - Insights on key performance indicators for inbound and outbound tourism at the global, regional and national levels. UNWTO Tourism Dashboard. URL: https://www.unwto.org/unwto-tourism-dashboard 


\section{REFERENCES:}

1. Benedict, M.A., McMahon, E.T. (2006) Green infrastructure: linking landscapes and communities. Washington: Island Press, $299 \mathrm{p}$.

2. Bergman, E.M., Feser, E.J. (1999) Industrial and Regional Clusters: Concepts and Comparative Applications. Morgantown: Regional Research Institute, $408 \mathrm{p}$.

3. Butler, R. (2006) The Concept of a Tourist Area Cycle of Evolution: Implications for Management of Resources. Canadian Geographer, 24, 5-12.

4. Ceballos-Lascurain, H. (1996) Tourism, Ecotourism and Protected Areas: The State of Nature-Based Tourism around the World and Guidelines for Its Development. Cambridge: IUCN Publications, $301 \mathrm{p}$.

5. Trusova, N.V., Cherniavska, T.A., Pasieka, S.R., Hranovska, V.Hr., Prystemskyi, O.S., Demko, V.S. (2020) Innovative clustering of the region in the context of increasing competitive positions of the enterprises of the tourist-recreational destination. GeoJournal of Tourism and Geosite, 33(3), 1126-1134.

6. Trusova, N.V., Kyrylov, Yu.Y., Hranovska, V.Hr., Prystemskyi, O.S., Sakun, A.Zh. (2020) The imperatives of the development of the tourist services market in spatial polarization of the regional tourist system. GeoJournal of Tourism and Geosites, 29(2), 565-582.

7. Gorina, G.O., Barabanova, V.V., Bohatyryova, G.A., Nikolaichuk, O.A., Romanukha, O.M. (2020) Clustering of regional tourism service markets according to indicators of the functioning of subjects of tourism activity. Journal of Geology, Geography and Geoecology, vol. 29, no. 4, pp. 684-692.

8. Cunha, J. (2005) Tourism Cluster Competitiveness and Sustainability: Proposal for a Systemic Model to Measure the Impact of Tourism on Local Development. Brazilian Administration Review, 2(2), 47-62.

9. Frederick, S., Simmons, M., Gallagher, M. (2013) The ecological imperative for environmental design and planning. Frontiers in Ecology and the Environment, 11(7), 355-361.

10. Goeldner, C.R., Ritchie, J.R. (2009) Tourism: principles, practices, philosophies. Hoboken: John Wiley \& Sons, Inc., $626 \mathrm{p}$.

11. Hall, C.M., Page, S.J. (2014) The Geography of Tourism and Recreation: Environment, Place and Space. New York: Routledge, $470 \mathrm{p}$.

12. Hardin, G. (1968) The Tragedy of the Commons. Science, 162(3859), 1243-1248.

13. Kuśen, E.A. (2010) System of tourism attractions. Tourism, 58(4), 409-424.

14. Lindqvist, G., Solvell, O., Ketels, Ch. (2013) The Cluster Initiative Greenbook 2.0. Stockholm: Ivory Tower Publishers, $66 \mathrm{p}$.

15. Nordin, S. (2003) Tourism Clustering \& Innovation: path to economic growth and development. Östersund: European Tourism Research Institute, $90 \mathrm{p}$.

16. Selin, S. (1999) Developing a typology of sustainable tourism partnerships. Journal of Sustainable tourism, 7(3), 260-273.

17. Sevenant, M., Antrop, M. (2009) Cognitive attributes and aesthetic preferences in assessment and differentiation of landscapes. Journal of Environmental Managemen, 90, 2889-2899.

18. The UNWTO Tourism Dashboard - Insights on key performance indicators for inbound and outbound tourism at the global, regional and national levels. UNWTO Tourism Dashboard. Retrieved from: https://www.unwto.org/ unwto-tourism-dashboard 